\title{
Mapping of quantitative trait loci for reproductive traits in pigs
}

\author{
J.P. Bidanel \\ INRA, UMR 1313 Génétique Animale et Biologie Intégrative, 78350, Jouy-en-Josas, France
}

This paper reviews the major approaches used to map quantitative trait loci (QTL) and current knowledge about QTL affecting reproductive trait loci in pigs. Three different approaches, i.e. functional candidate gene analyses, genome-wide linkage studies (GWLS) and genome-wide association studies (GWAS) have been used to map QTL in pigs. The interest and limits of each of the three approaches are discussed. Candidate genes and QTL have been reviewed based on PigQTLdb at http://www.animalgenome. org. A total of 29 candidate genes affecting reproductive traits located on 14 autosomes have been considered. Some of them are well established results, but most results originate from single studies of limited scale and need to be confirmed. Several thousands of QTL affecting 15 male and 15 female reproductive traits have been identified on 17 and 19 different chromosomes, respectively, using GWLS. Yet, the majority of them are only putative QTL and few QTL regions overlap between studies. Epistatic interactions between QTL appear as rather important in the single study investigating the effects of epistasis on pig reproductive traits. A large number of QTL distributed over almost all pig chromosomes have been identified in the single GWAS study published so far for pig reproductive traits. Use of sequence data, of more complex genetic models and of integrative biology approaches should be considered for more thoroughly investigating the genetic architecture of pig reproductive traits in the future.

\section{Introduction}

The development of genomics in the last 25 years has revolutionized the research methods and tools in genetics and, more generally, in biology. This revolution has been largely driven by the human genetics area. Considerable resources have indeed been mobilized to decipher the human genome and its variations. The huge progress obtained in humans has largely contributed to the advancement of livestock genetics and genomics due to both technological leaps (genotyping, microarrays, sequencing, bioinformatics...) and to the input of comparative genomics on the knowledge of animal genomes.

Genomics has not only allowed the whole sequence of most livestock genomes to be deciphered, but has also allowed to get a much better understanding of the genetic architecture of complex traits. An increasing number of polymorphisms responsible for variations in simple Mendelian traits (e.g. Andersson and Plastow 2011), or having major effects on quantitative traits (Milan, et al. 2000, Van Laere, et al. 2003) have been or are about to be identified. Several thousands of Quantitative Trait Loci (QTL) associated with phenotypic variations have been mapped on livestock genomes (e.g. Bidanel and Rothschild 2002). In parallel, the other 
"omics" technologies, i.e. transcriptomics, proteomics and metabolomics, are powerful tools to better understand the functioning of animal genomes, identify gene and metabolic networks involved in key biological functions, and contribute to the ambitious goal of bridging the gap between genotype and phenotype.

Reproduction is a major biological function in all animal species. Although pig is known to have a very high reproductive efficiency, with fertility rates close to $90 \%$ and average numerical productivities that approach or exceed 30 piglets / sow / year, reproduction traits, especially prolificacy, are essential components of the economic efficiency pig production systems. Litter size has been a major component of the breeding goal in major pig dam lines over the last 20 years. Rather large genetic gains, in the order of 30 to $40 \%$ of the mean, have obtained on litter size at birth in several pig populations (Guéry, et al. 2009, Tribout, et al. 2003) despite the low heritability of this trait.

Nevertheless, these gains remain limited by the low heritability, the late and sex-limited expression of reproductive traits. These limitations can be circumvented by using marker-assisted (MAS) or genomic selection (GS) methods, which are thus likely to be of high interest to improve the efficiency of selection for these traits. Additionally, reproductive traits are strongly influenced by non-additive genetic effects, as shown by the large heterosis values obtained in crosses between pig breeds (Bidanel 2011). A better understanding of gene interactions underlying these non additive effects is also of high interest to improve the efficiency of livestock breeding and management. This paper reviews the results obtained over the last 20 years on the genetic architecture of reproductive traits in pigs and discusses challenges and opportunities offered in the coming years by recent high throughput genomic tools.

\section{Methods to investigate the genetic architecture of complex traits.}

The methods used to investigate the influence of genes on phenotypic variability have been closely related to available genetic and genomic tools. The oldest methods, based on the polygenic infinitesimal model, use pedigree and phenotype information to estimate genetic parameters, i.e. the genetic part of phenotypic (co)variances. Even if they are outside the scope of this article, it should be noted that these methods are still very useful in animal breeding, and are a necessary first step of the analysis of a new trait so as to make sure it is at least partly genetically determined. several reviews of genetic parameters of reproductive traits are available in the literature (see Bidanel 2011 for the most recent one). We will consequently not present them, but just point out that most of the reproductive traits have low to moderate heritability values.

The next step, since DNA polymorphism has became accessible, has been to relate variations at the DNA level to phenotypic variation. Several methods have been used depending on the available technologies and resources. The first one is to identify a gene involved in a biological function, find one or several polymorphisms in this gene, and then test the effects of these polymorphisms on traits characterizing the biological function investigated. This approach is known as functional candidate gene (FCG) analysis. FCG analyses have the great merit of being rather inexpensive and simple to implement. This is probably the main reason why this approach has been widely used by a large number of research teams since the publication of the article of Rothschild, et al. (1996) on the effects of the estrogen receptor gene on litter size.

FCG analyses conversely have several important limits. First, the functional importance of a gene does not imply that variations of its sequence result in variations at the phenotypic level. The vast majority of FCG analyses actually leads to non significant results. When significant results are obtained, the polymorphisms investigated have a "significant" probability of being the 
causative polymorphism, particularly if it has been selected on the basis of functional arguments (e.g. it changes the structure of the translated protein). In practice, causal polymorphisms have rarely been identified using FCG analyses. In most cases, the polymorphisms investigated are likely to be only markers in linkage disequilibrium (LD) with the causal mutation, which can have nothing to do with the gene under investigation. In such a situation, the estimated effect of the polymorphism is an "apparent" effect, which is a function of the effect of the causal polymorphism and of its linkage disequilibrium with the marker.

In spite of its limitations, FCG analysis can be very interesting within population, as LD often extends over short distances. In this situation, a significant effect means that there is probably a causal polymorphism close to the marker. This is conversely not relevant when the LD extends over large distances, as in crosses between populations or in newly formed synthetic lines (Zhao, et al. 2003). In all cases, using single marker results from a FCG analysis in a marker or candidate gene assisted selection program appears as rather risky. If MAS is considered as a method of interest, it as much wiser to have two or more markers flanking the causal polymorphism to optimize the efficiency of MAS. Yet, direct selection for the causal polymorphism when it has been identified (i.e. gene assisted selection) or genomic selection, which appear as more powerful methods than MAS, should be preferred when possible.

The positional FCG analysis is a commonly used variant of the FCG approach. Its principle is to find functional candidate genes within the confidence interval of a QTL position. It is a potentially quite powerful approach if the confidence interval of the QTL is rather small. It is much more difficult when QTL have been detected in an F2 design between divergent breeds for the above-mentioned reasons of LD extent over large distances (Zhao, et al. 2003), unless strong functional arguments exist in favor of a gene / a polymorphism.

The other approaches are not based on functional arguments, but on the associations between closely linked markers / genes. They allow whole-genome QTL mapping to be performed, provided that a network of markers covering the genome is available, and are often used in this way. Two major types of methods have been used depending on marker technologies available.

In the 1990s, microsatellites were the first type of markers covering the entire genome that could be amplified using polymerase chain reaction and then genotyped on a large scale at a reasonable cost using automated sequencers. They led to the establishment of the first genetic maps of the entire genome (Archibald, et al. 1995, Rohrer, et al. 1996) and the establishment of a large number of QTL mapping programs (Bidanel and Rothschild 2002, Hu, et al. 2013). As microsatellite density is insufficient to give access to within-population LD, microsatellite based QTL mapping programs are based on within-family linkage disequilibrium, which requires designs with large half-sib families, or on F2 or backcross populations issued from crosses between divergent populations which are assumed to be fixed for different QTL alleles.

These microsatellite based programs have led to the detection of thousands of QTL, including a few hundred of QTL for reproductive traits. Their location often remains inaccurate, with confidence intervals of several centimorgans, and the generalization of the results to commercial populations is not straightforward. Yet, some studies have shown, for production traits, that QTL detected in crosses between divergent breeds can also be segregating in commercial populations (Evans, et al. 2003, Sanchez, et al. 2010). Fine-mapping programs have been developed by several teams (Berg, et al. 2006, Campbell, et al. 2003, Riquet, et al. 2011), but only one (Campbell, et al. 2003) dealt with reproductive traits. Moreover, apart from the identification of intron3 G3072A-IGF2 locus as a causative polymorphism for carcass fatness (Van Laere, et al. 2003), they have not yet led to the identification of causal polymorphisms.

Since the mid-2000s, the dramatic progress achieved in genome sequencing technologies has allowed to take advantage of a new type of markers, single nucleotide polymorphisms (SNP). 
Several millions of SNP are available throughout the genome, so that very dense genetic maps can easily be built. At the same time, the development of DNA chips has made it possible to genotype animals for tens of thousands (Ramos, et al. 2009), or even hundreds of thousands of markers (a 800,000 SNP chip is currently available in cattle) at a very low cost. This DNA chip technology has allowed the development of selection based on genetic marker indexes, i.e. genomic selection (GS). It also gives the opportunity to have a much more accurate mapping of QTL and to go further in the knowledge of the genetic architecture of complex traits. A mean coverage of 20 markers / morgan can indeed be expected with a 60,000 SNP chip, which is dense enough to have access to within-population LD in most pig populations. These SNP chips thus make it possible to perform whole-genome association studies (GWAS) directly in commercial populations. Optimal designs for GWAS are based on a large number of small nuclear families, which is favorable to ensure a good representation of the whole population. Genetic parameters can easily be estimated to ensure that there is enough genetic variation for association studies. Finally, they can easily be used as a first step towards the development of a reference population for genomic selection. In contrast, reference populations from genomic selection programs are highly valuable resources for the analysis of the genetic architecture of traits of interest, provided that the data are available to research teams.

Yet, in spite of their higher statistical power, QTL detected by GWAS are far from explaining the whole genetic variation of the traits investigated. This problem, known as the "missing heritability" problem in the human genetics literature, can be due to the insufficient size of experiments, which make it possible to identify only QTL with moderate to large effects, but also to the fact that the additive effects of individual genes cannot explain the whole genetic variation of a trait, which may also be due due to genetic interactions or epigenetic effects (Slatkin, 2009; Zuk et al. 2012).

\section{Effects of candidate genes on reproductive traits}

Candidate genes with significant effects on reproductive traits that were available in pig QTL database (http://www.animalgenome.org/cgi-bin/QTLdb/SS/index - accessed on January 2013) are given in Table 1. Most of the oldest references are pure FCG analyses, while some of the most recent references (Balcells, et al. 2011a, Balcells, et al. 2011b, Coster, et al. 2012) are positional FCG analyses based on previous QTL mapping designs. Pure FCG analyses first dealt with genes clearly involved in reproductive physiology, such as ESR, FSHB, FSHR, GNRHR, PRLR,... Genes that were less obviously involved in reproduction were then investigated, particularly for positional analyses. It has to be noted that a rather important fraction of the results are based on single study on a rather limited number of animals and should be interpreted with some caution. Results for some genes are based on larger samples of animals and / or involve several independent studies (e.g. ESR1, LEP, PRLR, ...), so that there is a very high probability that there is a causal mutation inside or in the vicinity of the gene. The polymorphisms investigated have not been shown to be causative. In the case of ESR1, population dependent effects even strongly suggest that at least one of the polymorphisms investigated is not causal.

The effects on reproductive traits of known major genes have also been investigated. The ryanodyne receptor (also called halothane sensitivity or Hal) locus (Fujii, et al. 1991) and the PRKAG3 (or RN) locus (Milan, et al. 2000) have been shown to have no or very limited effects on reproductive traits. Significant effects of the halothane gene region were reported in some studies, but they were probably due to a linked gene rather than Hal locus itself (Sellier, et al. 1987). QTL affecting reproduction traits have indeed been detected in the vicinity of both the $H A L$ and RN genes (Tables 2 and 3), so that apparent effects of Hal and RN on reproductive traits would occur in case of linkage disequilibrium with the QTL. An effect of the ICF2-Intron3- 


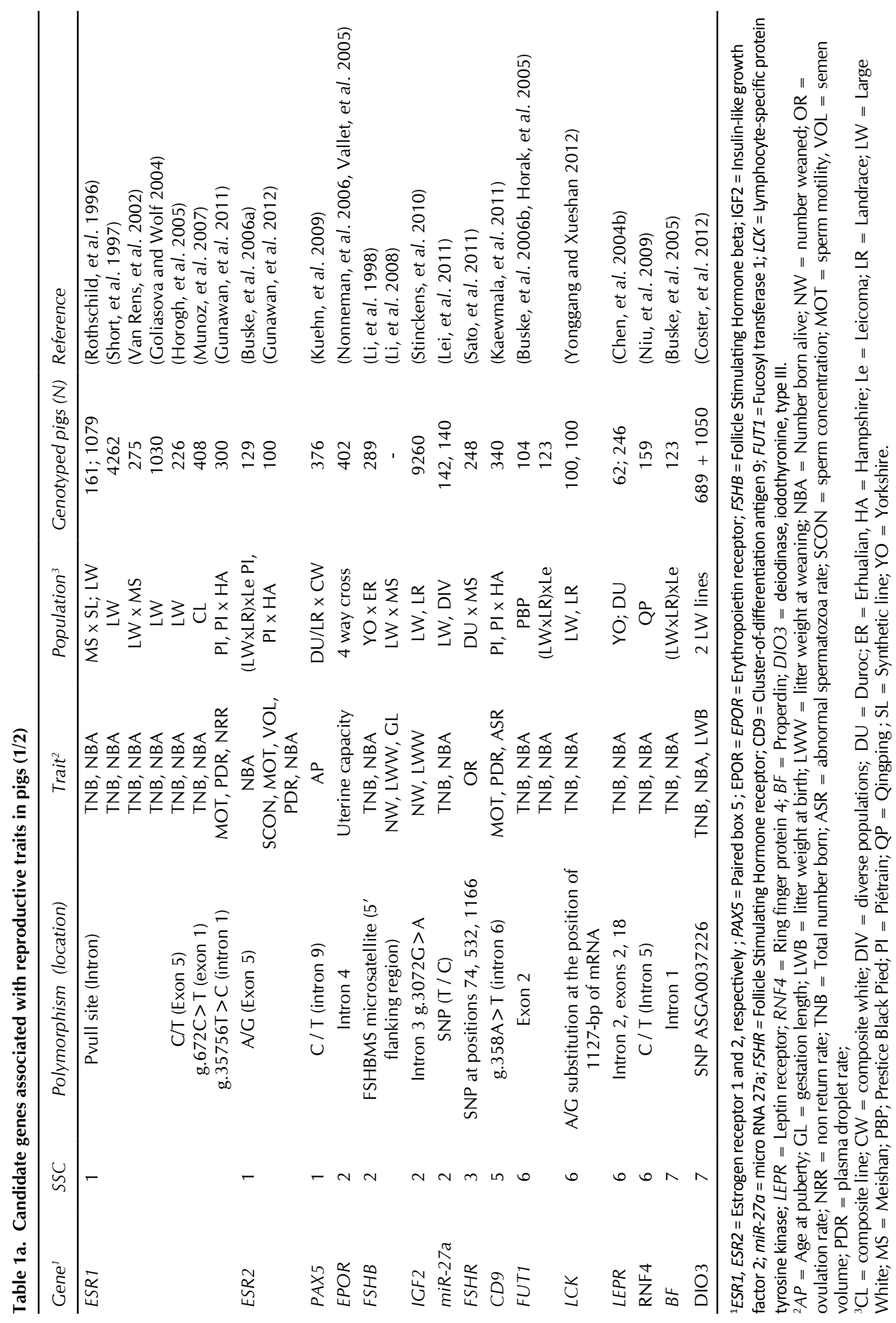




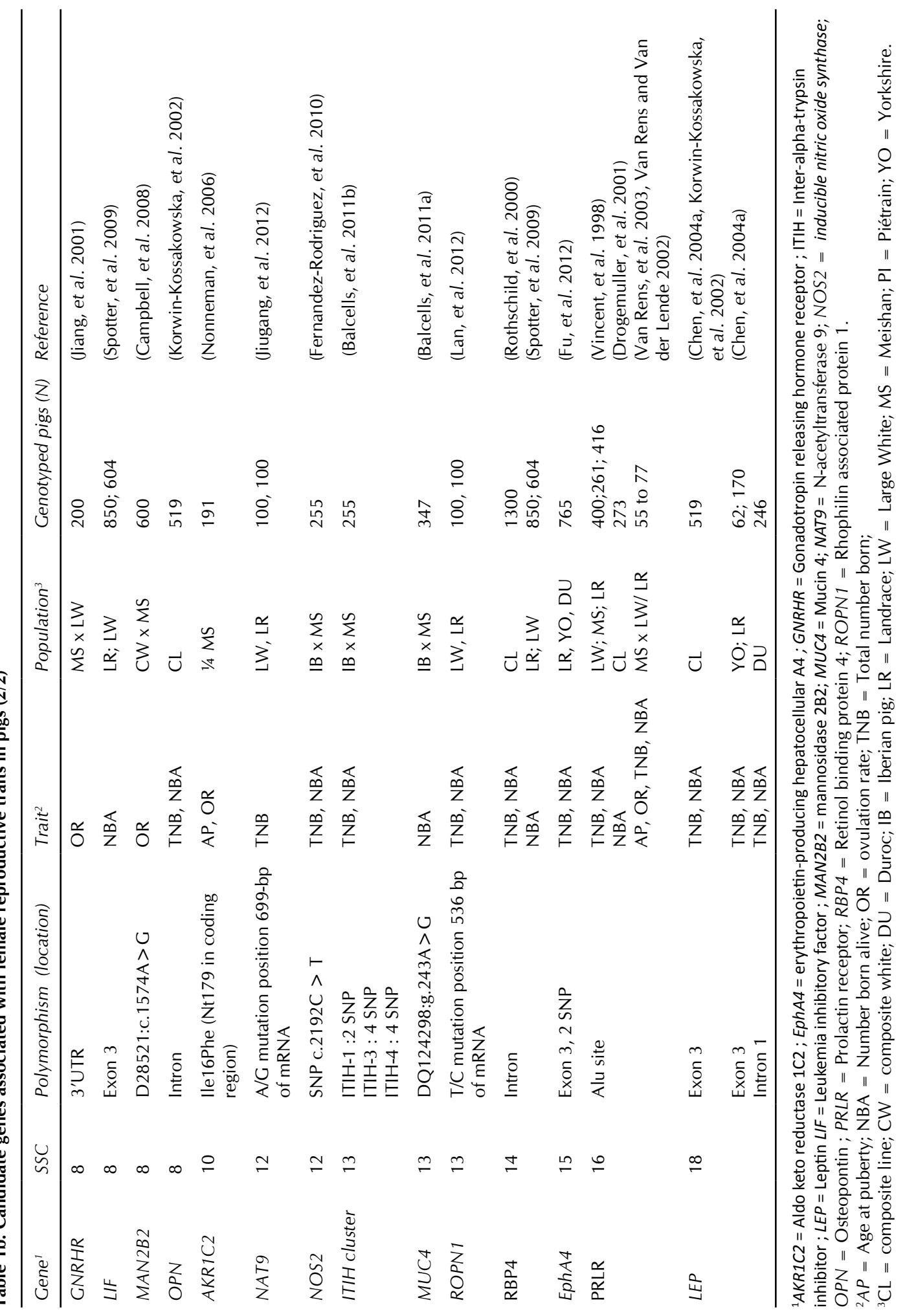


Table 2. QTL for male reproductive traits

\begin{tabular}{|c|c|c|c|c|c|}
\hline Trait & Pig chromosome & Population $^{1}$ & Size & \% variance & Reference \\
\hline Ejaculation duration & 6,17 & $\mathrm{DU} \times \mathrm{ER}$ & 177 & 7.7 to 7.9 & (Xing, et al. 2009) \\
\hline Ejaculation times & $6,16,17$ & $D U \times E R$ & 177 & 5.9 to 11.8 & (Xing, et al. 2009) \\
\hline \multicolumn{6}{|l|}{ Epididymal weight at } \\
\hline - 90 days of age & 2 & DU $x E R$ & 347 & 4.5 & (Ren, et al. 2009) \\
\hline - 180 days of age & $3,4,10,13,15$ & $\mathrm{LW} \times \mathrm{MS}$ & 487 & 1.9 to 4.3 & (Bidanel, et al. 2001) \\
\hline - 300 days of age & 3,7 & $D U \times E R$ & 347 & 4.5 to 27.3 & (Ren, et al. 2009) \\
\hline $\begin{array}{l}\text { Length of bulbo-urethral } \\
\text { glands }\end{array}$ & $1,3,7,13$ & $\mathrm{LW} \times \mathrm{MS}$ & 485 & 3.3 to 5.1 & (Bidanel, et al. 2001) \\
\hline Plasma FSH level & $\begin{array}{c}3,10, x \\
x\end{array}$ & $\begin{array}{l}\text { WC } \times M S \\
W C \times M S\end{array}$ & $\begin{array}{l}315 \\
132\end{array}$ & $\begin{array}{c}\mathrm{Np}^{2} \\
\mathrm{np}\end{array}$ & $\begin{array}{l}\text { (Rohrer, et al. 2001) } \\
\text { (Ford, et al. 2001) }\end{array}$ \\
\hline Plasma testosterone level & 7,13 & $D U \times E R$ & 347 & 7.3 to 14.3 & (Ren, et al. 2009) \\
\hline Semen volume & $3,15,18$ & $D U \times E R$ & 177 & 7.9 to 8.6 & (Xing, et al. 2009) \\
\hline \multicolumn{6}{|c|}{ Seminiferous tubular diameter } \\
\hline - at 90 days & $5,13,14, x$ & DU $x E R$ & 347 & 8.4 to 14.8 & (Ren, et al. 2009) \\
\hline - at 300 days & 16 & $D U \times E R$ & 347 & 14.8 & (Ren, et al. 2009) \\
\hline Seminal vesicles Weight & $\begin{array}{c}1,3,4,7,11,15 \\
16, x\end{array}$ & LW $\times$ MS & 481 & 2.5 to 21.8 & (Bidanel, et al. 2001) \\
\hline Daily sperm production & $x$ & WC $\times$ MS & 132 & $\mathrm{np}$ & (Ford, et al. 2001) \\
\hline Sperm abnormality rate & 4,9 & $D U \times E R$ & 177 & 8.8 to 11.8 & (Xing, et al. 2009) \\
\hline Sperm concentration & 17 & $D U \times E R$ & 177 & 9.5 & (Xing, et al. 2009) \\
\hline Sperm motility & 4 & DU $x$ ER & 177 & 6.3 & (Xing, et al. 2009) \\
\hline Sperm $\mathrm{pH}$ value & $2,6,9$ & DU $x E R$ & 177 & 5.7 to 9.8 & (Xing, et al. 2009) \\
\hline \multicolumn{6}{|l|}{ Testicular weight at : } \\
\hline - 60 days & $3, x$ & $\mathrm{DU} \times \mathrm{MS}$ & 449 & 5.0 to 9.0 & (Sato, et al. 2003) \\
\hline - 90 days & $1, X$ & DU $x E R$ & 347 & 9.1 to 20.6 & (Ren, et al. 2009) \\
\hline - 180 days & $\begin{array}{c}4,7,10,13 \\
17, x\end{array}$ & $\mathrm{LW} \times \mathrm{MS}$ & 487 & 3.5 to 19.6 & (Bidanel, et al. 2001) \\
\hline \multirow[t]{2}{*}{ - 220 days } & $X$ & WC $\times M S$ & 315 & $\mathrm{np}$ & (Rohrer, et al. 2001) \\
\hline & $x$ & WC x MS & 132 & $\mathrm{np}$ & (Ford, et al. 2001) \\
\hline - 300 days & $1,5,7, x$ & $\mathrm{DU} \times \mathrm{ER}$ & 347 & 4.8 to 14.7 & (Ren, et al. 2009) \\
\hline
\end{tabular}

${ }^{1} \mathrm{DU}=$ Duroc; $\mathrm{ER}=$ Erhualian, $\mathrm{LW}=$ Large White; $\mathrm{MS}=$ Meishan; WC = White European breed cross

${ }^{2} \mathrm{np}=$ not provided

G3072A mutation (Van Laere, et al. 2003) on sow prolificacy has recently been reported (Stinckens, et al. 2010) but, to our knowledge, it is not yet known whether it is a direct or an apparent effect of G3072A mutation.

\section{QTL affecting reproductive traits}

The main features of male and female reproductive trait QTL reported in in pig QTL database (http://www.animalgenome.org/cgi-bin/QTLdb/SS/index - accessed on January 2013) are 
Table 3a. QTL for female reproductive traits (1/2)

\begin{tabular}{|c|c|c|c|c|c|}
\hline Trait & Pig chromosome & Population ${ }^{1}$ & Size & $\%$ variance & Reference \\
\hline \multirow[t]{5}{*}{ Age at puberty } & $1,4,6,7,13$ & LW $\times$ MS & 476 & 3.0 to 10.0 & (Bidanel, et al. 2008) \\
\hline & $7,8,12$ & $L W \times L R$ & 295 & 2.7 to 9.7 & (Cassady, et al. 2001) \\
\hline & 15 & $L W \times L R$ & 295 & $\mathrm{np}^{2}$ & (Holl, et al. 2004) \\
\hline & 1,10 & WC $\times$ MS & 344 & $\mathrm{np}$ & (Rohrer, et al. 1999) \\
\hline & $1,7,8,17$ & $D U \times E R$ & 454 & 2.0 to 8.0 & (Yang, et al. 2008) \\
\hline \multirow[t]{8}{*}{ Ovulation rate } & $4,5,7,9,13$ & $\mathrm{LW} \times \mathrm{MS}$ & 502 & 3.9 to 5.9 & (Bidanel, et al. 2008) \\
\hline & 9 & $L W \times L R$ & 295 & 3.4 & (Cassady, et al. 2001) \\
\hline & $4,8,13,15$ & $L W \times L R$ & 114 & 5.1 to 10.9 & (Rathje, et al. 1997) \\
\hline & $3,8,9,10,15$ & WC $\times$ MS & 344 & $\mathrm{np}$ & (Rohrer, et al. 1999) \\
\hline & 3 & $\mathrm{DU} \times \mathrm{MS}$ & 234 & $\mathrm{np}$ & (Sato, et al. 2006) \\
\hline & $7,8,15$ & $\mathrm{YO} \times \mathrm{MS}$ & 104 & $\mathrm{np}$ & (Wilkie, et al. 1999) \\
\hline & 8 & $\mathrm{YO} \times \mathrm{MS}$ & 108 & 17.4 & $\begin{array}{l}\text { (Braunschweig, et al. } \\
\text { 2001) }\end{array}$ \\
\hline & 8 & WC $\times$ MS & 600 & $\mathrm{np}$ & (Campbell, et al. 2003) \\
\hline Weight of ovaries & $\begin{array}{l}4,6,7,9,12,13,14 \\
15,18\end{array}$ & $\mathrm{LW} \times \mathrm{MS}$ & 502 & 2.3 to 7.0 & (Rosendo, et al. 2012) \\
\hline Number of embryos & $9,12,18$ & $\mathrm{LW} \times \mathrm{MS}$ & 468 & 2.8 to 7.2 & (Bidanel, et al. 2008) \\
\hline Uterine capacity & 8 & WC $\times M S$ & 187 & & (Rohrer, et al. 1999) \\
\hline Uterine horn length & $1,5,6,7,9,11,12,13$ & LW $\times$ MS & 465 & 2.7 to 9.2 & (Rosendo, et al. 2012) \\
\hline Uterine horn weight & $\begin{array}{l}1,2,4,5,7,9,12 \\
13, X\end{array}$ & LW $\times$ MS & 465 & 2.3 to 4.5 & (Rosendo, et al. 2012) \\
\hline Reproductive tract weight & $1,5,9,12,14,18, x$ & $\mathrm{LW} \times \mathrm{MS}$ & 465 & 1.8 to 4.6 & (Rosendo, et al. 2012) \\
\hline \multirow[t]{2}{*}{ Gestation length } & $1,9,15$ & $\mathrm{YO} \times \mathrm{MS}$ & 104 & 9.4 to 23.6 & (Wilkie, et al. 1999) \\
\hline & $\begin{array}{l}1,2,3,4,5,6,7,9 \\
10,11,13,14,15,16 \\
17,18\end{array}$ & $L W, L W \times L R$ & 683 & $\mathrm{np}$ & (Onteru, et al. 2012) \\
\hline \multirow[t]{2}{*}{ Number mummified } & $2,6,12$ & $L W \times L R$ & 279 & $\mathrm{np}$ & (Holl, et al. 2004) \\
\hline & $\begin{array}{l}1,2,3,4,5,6,7,8,9 \\
10,11,13,14,15,16, \\
17,18, X\end{array}$ & LW, LW x LR & 683 & $\mathrm{np}$ & (Onteru, et al. 2012) \\
\hline
\end{tabular}

${ }^{1} \mathrm{DU}=$ Duroc; $\mathrm{ER}=$ Erhualian, $\mathrm{IB}=$ Iberian pig; $\mathrm{LR}=$ Landrace; $\mathrm{LW}=$ Large White; MS = Meishan; WC = White European breed cross; YO = Yorkshire

${ }^{2} \mathrm{np}=$ not provided

summarized in Tables 2 and 3, respectively. The limited number of QTL mapping programs for male reproductive traits have been performed using crosses between early maturing Chinese and American / European breeds. Most QTL have a rather low to moderate effect (less than $10 \%$ of trait variance), except on chromosome X, where QTL explaining up to $20 \%$ of the variance of several traits, i.e. testicular weight, seminal vesicles weight and seminiferous tubular diameter, have been detected. Alleles from Chinese breeds increase testes weight at young ages, but tend to reduce it at older ages. The SERPINA7 gene, which regulates the availability of thyroid hormones within tissues has been reported as an interesting positional candidate for this QTL by Ren, et al. (2009), but its potential implication remains to be investigated. No 
Table 3b. QTL for female reproductive traits (2/2)

\begin{tabular}{|c|c|c|c|c|c|}
\hline Trait & Pig chromosome & Population ${ }^{1}$ & Size & $\%$ variance & Reference \\
\hline \multirow[t]{7}{*}{ Total number born } & 11 & $L W \times L R$ & 279 & 5.1 & (Cassady, et al. 2001) \\
\hline & $7,12,14,17$ & LW/LR $\times$ MS & 269 & 2.7 to 8.8 & (De Koning, et al. 2001) \\
\hline & 8 & LW $\times$ MS & 152 & $n p^{2}$ & (King, et al. 2003) \\
\hline & 7,15 & $D U \times E R$ & 299 & 2.8 to 4.3 & (Li, et al. 2009) \\
\hline & 13,17 & $\mathrm{IB} \times \mathrm{MS}$ & 881 & $\mathrm{np}$ & (Noguera, et al. 2009) \\
\hline & 6 & YO $\times$ MS & 104 & $\mathrm{np}$ & (Wilkie, et al. 1999) \\
\hline & $\begin{array}{l}1,2,3,4,6,7,8,9 \\
12,13,14,15,16 \\
17,18\end{array}$ & $L W, L W \times L R$ & 683 & $\mathrm{np}$ & (Onteru, et al. 2012) \\
\hline \multirow[t]{6}{*}{ Number of stillborn } & 5,13 & $L W \times L R$ & 279 & 7.9 & (Cassady, et al. 2001) \\
\hline & 12,14 & $L W \times L R$ & 279 & $\mathrm{np}$ & (Holl, et al. 2004) \\
\hline & 7,8 & $\mathrm{DU} \times \mathrm{ER}$ & 299 & 3.7 to 5 & (Li, et al. 2009) \\
\hline & $6,11,14$ & LW, LR & & $\mathrm{np}$ & (Tribout, et al. 2008) \\
\hline & 4 & $\mathrm{YO} \times \mathrm{MS}$ & 104 & $\mathrm{np}$ & (Wilkie, et al. 1999) \\
\hline & $\begin{array}{l}1,2,3,4,5,6,8,9 \\
10,12,13,14,15,16 \\
17,18\end{array}$ & $L W, L W \times L R$ & 683 & $\mathrm{np}$ & (Onteru, et al. 2012) \\
\hline \multirow[t]{5}{*}{ Number born alive } & 11 & $L W \times L R$ & 279 & $\mathrm{np}$ & (Cassady, et al. 2001) \\
\hline & 6,15 & $\mathrm{DU} \times \mathrm{ER}$ & 299 & 3.7 to 5 & (Li, et al. 2009) \\
\hline & 13,17 & $\mathrm{IB} \times \mathrm{MS}$ & 881 & $\mathrm{np}$ & (Noguera, et al. 2009) \\
\hline & $7,16,18$ & LW, LR & & $\mathrm{np}$ & (Tribout, et al. 2008) \\
\hline & $\begin{array}{l}1,2,3,4,6,10,11 \\
12,13,14,15,16\end{array}$ & $L W, L W \times L R$ & 683 & $\mathrm{np}$ & (Onteru, et al. 2012) \\
\hline Removal parity & $\begin{array}{l}1,5,8,9,11,12,13 \\
14,16\end{array}$ & $L W, L W \times L R$ & 818 & $\mathrm{np}$ & (Onteru, et al. 2011) \\
\hline $\begin{array}{l}\text { Nonproductive days / } \\
\text { herd life }\end{array}$ & $9,12,14,17, x$ & $L W, L W \times L R$ & 818 & $\mathrm{np}$ & (Onteru, et al. 2011) \\
\hline
\end{tabular}

${ }^{1} \mathrm{DU}=$ Duroc; $\mathrm{ER}=$ Erhualian, $\mathrm{IB}=$ Iberian pig; $\mathrm{LR}=$ Landrace; $\mathrm{LW}=$ Large White; $M S$ = Meishan; WC = White European breed cross; YO = Yorkshire

${ }^{2} \mathrm{np}=$ not provided

fine mapping of autosomal QTL has been carried out as yet and the localization interval of the QTL remains very large (generally above $20 \mathrm{cM}$ ).

QTL for female reproductive traits are shown in Table 3. They were all detected using GWLS except in the recent GWAS results of Onteru, et al. $(2011 ; 2012)$ which will be discussed later. The most heritable traits, i.e. age at puberty ovulation rate and uterine dimensions have the largest number of QTL. QTL for age at puberty have been detected on 10 different chromosomes, with overlapping confidence intervals from independent studies on SSC1, on SSC7 in the SLA complex region and at the extremity of the short arm of SSC8. QTL for ovulation rate have been detected on 9 different chromosomes, with QTL from independent studies located on two different regions of SSC8, the first one in the centromeric region (Wilkie, et al. 1999), the second one in the telomeric part of SSC8 short arm. 
The position of the 2 SSC8 QTL has been refined by, respectively, Braunschweig, et al. (2001) and Campbell, et al. (2003). Campbell, et al. (2008) proposed the mannosidase 2B2 (MAN2B2) locus as a positional candidate, but the causal polymorphism does not seem to have been identified so far. A C/G substitution in the 3' UTR of a functional candidate locus, i.e. GNRHRH, located in the centromeric part of SSC 8, was found to affect ovulation rate by Jiang, et al. (2001).

QTL affecting litter size traits have been detected on 13 different chromosomes with microsatellite markers, but most of them are only putative results and the overlap between studies is rather limited. Indeed, overlaps between confidence intervals concern the results of Bidanel, et al. (2001), Wilkie, et al. (1999) and Li, et al. (2009) on SSC 6, of De Koning, et al. (2001), Tribout, et al. (2008) and Li, et al. (2009) on SSC 7, of Bidanel, et al. (2001), Wilkie, et al. (1999) and Noguera, et al. (2009) on SSC 13 and, finally, of De Koning, et al. (2001) and Noguera, et al. (2009) on SSC 17. Some overlaps with FCG results can also be found. The LEPR locus is located in the confidence interval of the above mentioned SSC 6 QTL. The SSC 7 QTL are located in the vicinity of the properdin locus $(B F)$. The prolactin receptor locus $(P R L P)$ is located on SSC 16, close to the confidence interval bound of the QTL affecting number born alive mapped by Tribout, et al. (2008).

The papers of Onteru, et al. $(2011 ; 2012)$ are, to our knowledge, the only ones who report QTL results based on the PorcineSNP60 BeadChip. They found a very large number of QTL that are located much more accurately than previous results. Most of them correspond to new QTL regions. Even if they have to be confirmed by other independent studies, these results are a clear illustration of the high detection power of dense sets of SNP markers. They also show that the genetic architecture of complex traits such as reproductive traits depends on larger numbers of loci than was expected 10 years ago.

Finally, it should be emphasized that the simple additive models that have been used so far are unlikely to correctly describe the complex gene interaction pathways underlying the genetic architecture of traits that are known to have a high degree of complexity. Noguera, et al. (2009) used a more complex model involving two-QTL with interaction models and found not less than 18 epistatic QTL affecting number born alive. A lot of work remains to be done using more complex models on larger data sets. Additional major challenges for the future include: 1) the use of sequence data in QTL mapping studies; 2) the integration of transcriptome, proteome and metabolome data for both improving QTL mapping power and more getting a much better understanding the complex pathways underlying complex biological functions such as reproduction; 3 ) to model gene functioning and enter the area of predictive biology.

\section{References}

Andersson, L, and G Plastow 2011 Molecular genetics of coat colour variation. In The genetics of the pig edn 2 pp 38-50. Eds MF Rothschild and A Ruvinsky. Wallingford UK: CABI.

Archibald, AL, CS Haley, JF Brown, S Couperwhite, HA McQueen, D Nicholson, W Coppieters, A Vandeweghe, A Stratil, AK Wintero, M Fredholm, NJ Larsen, VH Nielsen, D Milan, N Woloszyn, A Robic, M Dalens, J Riquet, J Gellin, JC Caritez, G Burgaud, L Ollivier, JP Bidanel, M Vaiman, C Renard, H Geldermann, R Davoli, D Ruyter, EJM Verstege, MAM Groenen, W Davies, B Hoyheim, A Keiserud, L Andersson, H Ellegren, M Johansson, L Marklund,
JR Miller, DVA Dear, E Signer, AJ Jeffreys, C Moran, P Letissier, Muladno, MF Rothschild, CK Tuggle, D Vaske, J Helm, HC Liu, A Rahman, TP Yu, RG Larson, and CB Schmitz 1995 The PigMaP Consortium linkage map of the Pig (Sus Scrofa). Mammalian Genome 6 157-175.

Balcells, I, A Castello, A Mercade, JL Noguera, A Fernandez-Rodriguez, A Sanchez, and A Tomas 2011a Analysis of porcine MUC4 gene as a candidate gene for prolificacy QTL on SSC13 in an Iberian x Meishan F-2 population. BMC Genetics 1293.

Balcells, I, A Castello, JL Noguera, A FernandezRodriguez, A Sanchez, and A Tomas 2011b 
Sequencing and gene expression of the porcine ITIH SSC 13 cluster and its effect on litter size in an Iberian $x$ Meishan F-2 population. Animal Reproduction Science 128 85-92.

Berg, F, S Stern, K Andersson, L Andersson, and M Moller 2006 Refined localization of the FAT1 quantitative trait locus on pig chromosome 4 by marker-assisted backcrossing. BMC Genetics 717.

Bidanel, JP 2011 Biology and genetics of reproduction. In The genetics of the pig edn 2 pp 218-241. Eds MF Rothschild and A Ruvinsky. Wallingford UK: CABI.

Bidanel, JP, A Prunier, N lannuccelli, and D Milan 2001 Detection of quantitative trait loci for male and female reproductive traits in Meishan x Large White F2 pigs, $52^{\text {nd }}$ Annual Meeting of the European Association for Animal Production. Budapest, Hungaria.

Bidanel, JP, A Rosendo, N lannuccelli, J Riquet, H Gilbert, JC Caritez, Y Billon, Y Amigues, A Prunier, and D Milan 2008 Detection of quantitative trait loci for teat number and female reproductive traits in Meishan X Large White F2 pigs. Animal 2 813-820.

Bidanel, JP, and M Rothschild 2002 Current status of quantitative trait locus mapping in pigs. Pig News and Information 23 39N-54N.

Braunschweig, MH, AA Paszek, JI Weller, Y Da, RJ Hawken, MB Wheeler, LB Schook, and LJ Alexander 2001 Generation and exploration of a dense genetic map in a region of a QTL affecting corpora lutea in a Meishan x Yorkshire cross. Mammalian Genome 12 719-723.

Buske, B, C Brunsch, K Zeller, P Reinecke, and G Brockmann 2005 Analysis of properdin (BF) genotypes associated with litter size in a commercial pig cross population. Journal of Animal Breeding and Genetics 122 259-263.

Buske, B, I Sternstein, M Reissmann, and G Brockmann 2006a Detection of novel single-nucleotide polymorphisms (SNPs) in the CYP21 gene and association analysis of two SNPs for CYP21 and ESR2 with litter size in a commercial sow population. Journal of Animal Breeding and Genetics 123 343-348.

Buske, B, I Sternstein, M Reissmann, P Reinecke, and G Brockmann 2006b Analysis of association of GPX5, FUT1 and ESR2 genotypes with litter size in a commercial pig cross population. Archiv fur Tierzucht 49 259-268.

Campbell, EM, DJ Nonneman, LA Kuehn, and GA Rohrer 2008 Genetic variation in the mannosidase $2 \mathrm{~B} 2$ gene and its association with ovulation rate in pigs. Animal Genetics 39 515-519.

Campbell, EMG, D Nonneman, and GA Rohrer 2003 Fine mapping a quantitative trait locus affecting ovulation rate in swine on chromosome 8. Journal of Animal Science 81 1706-1714.

Cassady, JP, RK Johnson, D Pomp, GA Rohrer, LD Van Vleck, EK Spiegel, and KM Gilson 2001 Identification of quantitative trait loci affecting reproduction in pigs. Journal of Animal Science 79 623-633.

Chen, C, T Chang, and H Su 2004a Genetic polymorphisms in porcine leptin gene and their association with reproduction and production traits. Australian Journal of Agricultural Research 55 699-704.

Chen, CC, T Chang, and HY Su 2004b Characterization of porcine leptin receptor polymorphisms and their association with reproduction and production traits. Animal Biotechnology 15 89-102.

Coster, A, O Madsen, HCM Heuven, B Dibbits, MAM Groenen, JAM van Arendonk, and H Bovenhuis 2012 The Imprinted Gene DIO3 Is a Candidate Gene for Litter Size in Pigs. PLoS One 72.

De Koning, DJ, AP Rattink, B Harlizius, MAM Groenen, EW Brascamp, and JAM Van Arendonk 2001 Detection and characterization of quantitative trait loci for growth and reproduction traits in pigs. Livestock Production Science 72 185-198.

Drogemuller, C, H Hamann, and O Distl 2001 Candidate gene markers for litter size in different German pig lines. Journal of Animal Science 79 2565-2570.

Evans, GJ, E Giuffra, A Sanchez, S Kerje, G Davalos, O Vidal, S Illan, JL Noguera, L Varona, I Velander, OI Southwood, DJ de Koning, CS Haley, GS Plastow, and $\mathbf{L}$ Andersson 2003 Identification of quantitative trait loci for production traits in commercial pig populations. Genetics 164 621-627.

Fernandez-Rodriguez, A, C Rodriguez, L Varona, I Balcells, JL Noguera, C Ovilo, and AI Fernandez 2010 Analysis of candidate genes underlying two epistatic quantitative trait loci on SSC12 affecting litter size in pig. Animal Genetics 41 73-80.

Ford, JJ, TH Wise, DD Lunstra, and GA Rohrer 2001 Interrelationships of porcine $\mathrm{X}$ and $\mathrm{Y}$ chromosomes with pituitary gonadotropins and testicular size. Biology of Reproduction 65 906-912.

Fu, Y, J Fu, and A Wang 2012 Association of EphA4 polymorphism with swine reproductive traits and mRNA expression of EphA4 during embryo implantation. Molecular biology reports 392689 2696.

Fujii, J, K Otsu, F Zorzato, S Deleon, VK Khanna, JE Weiler, PJ Obrien, and DH Maclennan 1991 Identification of a mutation in porcine ryanodine receptor associated with malignant hyperthermia. Science 253 448-451.

Goliasova, E, and J Wolf 2004 Impact of the ESR gene on litter size and production traits in Czech Large White pigs. Animal Genetics 35 293-297.

Guéry, L, T Tribout, and JP Bidanel 2009 Genetic parameters and genetic trends for litter size and pre-weaning mortality in French Landrace and Large White breeds, 60th Annual Meeting of the European Association for Animal Production, Barcelona, Spain, August 23-26, 2009, paper G.

Gunawan, A, MU Cinar, MJ Uddin, K Kaewmala, D Tesfaye, C Phatsara, E Tholen, C Looft, and K Schellander 2012 Investigation on association and expression of ESR2 as a candidate gene for boar sperm quality and fertility. Reproduction in Domestic Animals 47 782-790.

Gunawan, A, K Kaewmala, MJ Uddin, MU Cinar, D Tesfaye, C Phatsara, E Tholen, C Looft, and K 
Schellander 2011 Association study and expression analysis of porcine ESR1 as a candidate gene for boar fertility and sperm quality. Animal Reproduction Science 128 11-21.

Holl, JW, JP Cassady, D Pomp, and RK Johnson 2004 A genome scan for quantitative trait loci and imprinted regions affecting reproduction in pigs. Journal of Animal Science 82 3421-3429.

Horak, P, T Urban, and J Dvorak 2005 The FUT1 and ESR genes - their variability and associations with reproduction in Prestice Black-Pied sows. Journal of Animal Breeding and Genetics 122 210-213.

Horogh, G, A Zsolnai, I Komlosi, A Nyiri, I Anton, and L Fesus 2005 Oestrogen receptor genotypes and litter size in Hungarian Large White pigs. Journal of Animal Breeding and Genetics 122 56-61.

Hu, ZL, CA Park, XL Wu, and JM Reecy 2013 Animal QTLdb: an improved database tool for livestock animal QTL/association data dissemination in the postgenome era. Nucleic Acids Research 41 D871-D879.

Jiang, Z, JP Gibson, AL Archibald, and CS Haley 2001 The porcine gonadotropin-releasing hormone receptor gene (GNRHR): genomic organization, polymorphisms, and association with the number of corpora lutea. Genome 44 7-12.

Jiugang, Z, L Jing, and L Yonggang 2012 Characterization, expression profile, polymorphism and association of porcine NAT9 gene. Molecular biology reports 39 3137-3142.

Kaewmala, K, MJ Uddin, MU Cinar, C Grosse-Brinkhaus, E Jonas, D Tesfaye, C Phatsara, E Tholen, C Looft, and K Schellander 2011 Association study and expression analysis of CD9 as candidate gene for boar sperm quality and fertility traits. Animal Reproduction Science 125 170-179.

King, AH, Z Jiang, JP Gibson, CS Haley, and AL Archibald 2003 Mapping quantitative trait loci affecting female reproductive traits on porcine chromosome 8 . Biology of Reproduction 68 2172-2179.

Korwin-Kossakowska, A, M Kamyczek, D Cieslak, M Pierzchaa, and J Kury 2002 The effect of leptin (LEP), leptin receptor (LEPR) and osteopontin (OPN) gene polymorphism on selected reproduction traits of synthetic Line 990 sows. Animal Science Papers and Reports 20 159-168.

Kuehn, LA, DJ Nonneman, JM Klindt, and TH Wise 2009 Genetic relationships of body composition, serum leptin, and age at puberty in gilts. Journal of Animal Science 87 477-483.

Lan, J, J Zhao, and Y Liu 2012 Molecular cloning, sequence characterization, polymorphism and association analysis of porcine ROPN1 gene. Molecular biology reports 39 2739-2743.

Lei, B, S Gao, LF Luo, XY Xia, SW Jiang, CY Deng, YZ Xiong, and FE Li 2011 A SNP in the miR-27a gene is associated with litter size in pigs. Molecular biology reports 38 3725-3729.

Li, FE, SQ Mei, CY Deng, SW Jiang, B Zuo, R Zheng, JL Li, DQ Xu, MG Lei, and YZ Xiong 2008 Association of a microsatellite flanking FSHB gene with reproductive traits and reproductive tract components in pigs. Czech Journal of Animal Science 53 139-144.

Li, K, J Ren, Y Xing, Z Zhang, J Ma, Y Guo, and L Huang 2009 Quantitative trait loci for litter size and prenatal loss in a White Duroc * Chinese Erhualian resource population. Animal Genetics 40 963-966.

Li, N, YF Zhao, L Xiao, FJ Zhang, and YZ Chen 1998 Candidate gene approach for loci affecting litter size in pigs, Proceedings of the 6th World Congress on Genetics Applied to Livestock Production, pp. 183190. Armidale, Australia.

Milan, D, JT Jeon, C Looft, V Amarger, A Robic, M Thelander, C Rogel-Gaillard, S Paul, N Iannuccelli, L Rask, H Ronne, K Lundstrom, N Reinsch, J Gellin, E Kalm, P Le Roy, P Chardon, and L Andersson 2000 A mutation in PRKAG3 associated with excess glycogen content in pig skeletal muscle. Science $\mathbf{2 8 8}$ 1248-1251.

Munoz, G, C Ovilo, J Estelle, L Silio, A Fernandez, and C Rodriguez 2007 Association with litter size of new polymorphisms on ESR1 and ESR2 genes in a ChineseEuropean pig line. Genetics Selection Evolution 39 195-206.

Niu, BY, LZ Ye, FE Li, CY Deng, SW Jiang, MG Lei, and YZ Xiong 2009 Identification of polymorphism and association analysis with reproductive traits in the porcine RNF4 gene. Animal Reproduction Science 110 283-292.

Noguera, JL, C Rodriguez, L Varona, A Tomas, G Munoz, O Ramirez, C Barragan, M Arque, JP Bidanel, M Amills, C Ovilo, and A Sanchez 2009 A bi-dimensional genome scan for prolificacy traits in pigs shows the existence of multiple epistatic QTL. BMC Genomics 10636.

Nonneman, DJ, TH Wise, JJ Ford, LA Kuehn, and GA Rohrer 2006 Characterization of the aldo-keto reductase $1 \mathrm{C}$ gene cluster on pig chromosome 10 : possible associations with reproductive traits. BMC Veterinary Research 228.

Onteru, SK, B Fan, ZQ Du, DJ Garrick, KJ Stalder, and MF Rothschild 2012 A whole-genome association study for pig reproductive traits. Animal Genetics 43 18-26.

Onteru, SK, B Fan, MT Nikkilae, DJ Garrick, KJ Stalder, and MF Rothschild 2011 Whole-genome association analyses for lifetime reproductive traits in the pig. Journal of Animal Science 89 988-995.

Ramos, AM, RPMA Crooijmans, NA Affara, AJ Amaral, AL Archibald, JE Beever, C Bendixen, C Churcher, R Clark, P Dehais, MS Hansen, J Hedegaard, Z-L Hu, HH Kerstens, AS Law, H-J Megens, D Milan, D) Nonneman, GA Rohrer, MF Rothschild, TPL Smith, RD Schnabel, CP Van Tassell, JF Taylor, RT Wiedmann, LB Schook, and MAM Groenen 2009 Design of a high density SNP genotyping assay in the pig using SNPs identified and characterized by next generation sequencing technology. PLoS One 48.

Rathje, TA, GA Rohrer, and RK Johnson 1997 Evidence for quantitative trait loci affecting ovulation rate in pigs. Journal of Animal Science 75 1486-1494.

Ren, DR, J Ren, YY Xing, YM Guo, YB Wu, GC Yang, 
HR Mao, and LS Huang 2009 A genome scan for quantitative trait loci affecting male reproductive traits in a White Duroc * Chinese Erhualian resource population. Journal of Animal Science 87 17-23.

Riquet, J, H Gilbert, B Servin, M-P Sanchez, N Iannuccelli, Y Billon, J-P Bidanel, and D Milan 2011 A locally congenic backcross design in pig: a new regional fine QTL mapping approach miming congenic strains used in mouse. BMC Genetics 126.

Rohrer, GA, LJ Alexander, ZL Hu, TPL Smith, JW Keele, and CW Beattie 1996 A comprehensive map of the porcine genome. Genome Research 6 371-391.

Rohrer, GA, JJ Ford, TH Wise, JL Vallet, and RK Christenson 1999 Identification of quantitative trait loci affecting female reproductive traits in a multigeneration Meishan-White composite swine population. Journal of Animal Science 77 1385-1391.

Rohrer, GA, TH Wise, DD Lunstra, and JJ Ford 2001 Identification of genomic regions controlling plasma FSH concentrations in Meishan-White Composite boars. Physiological Genomics 6 145-151.

Rosendo, A, N lannuccelli, H Gilbert, J Riquet, Y Billon, Y Amigues, D Milan, and JP Bidanel 2012 Microsatellite mapping of quantitative trait loci affecting female reproductive tract characteristics in Meishan * Large White F 2 pigs. Journal of Animal Science 90 37-44.

Rothschild, M, C Jacobson, D Vaske, C Tuggle, L Wang, T Short, G Eckardt, S Sasaki, A Vincent, D McLaren, O Southwood, Hvd Steen, A Mileham, and G Plastow 1996 The estrogen receptor locus is associated with a major gene influencing litter size in pigs. Proceedings of the National Academy of Sciences of the United States of America 93 201-205.

Rothschild, MF, L Messer, A Day, R Wales, T Short, O Southwood, and G Plastow 2000 Investigation of the retinol-binding protein 4 (RBP4) gene as a candidate gene for increased litter size in pigs. Mammalian Genome 11 75-77.

Sanchez, M-P, G Le Mignon, N Iannuccelli, R Suzana, M Marie-José, N Dechamp, Y Billon, M Bouffaud, S Schwob, H Gilbert, J Riquet, J-P Bidanel, and D Milan 2010 Effects of 6 QTL on growth, carcass composition and ultimate $\mathrm{pH}$ of longissimus dorsi in 65 commercial or experimental sire pig families., Proc. $9^{\text {th }}$ World Congress on Genetics Applied to Livestock Production, pp. paper $n^{\circ}$ 0461-PP0462-0109. Leipzig, Germany.

Sato, S, K Atsuji, N Saito, M Okitsu, A Komatsuda, T Mitsuhashi, K Nirasawa, T Hayashi, Y Sugimoto, and E Kobayashi 2006 Identification of quantitative trait loci affecting corpora lutea and number of teats in a Meishan * Duroc F2 resource population. Journal of Animal Science 84 2895-2901.

Sato, S, T Hayashi, and E Kobayashi 2011 Fine mapping the number of corpora lutea quantitative trait loci on SSC3: Analysis of the porcine follicle-stimulating hormone receptor gene. Animal Science Journal 82 633-641.

Sato, S, Y Oyamada, K Atsuji, T Nade, E Kobayashi, T Mitsuhashi, K Nirasawa, A Komatsuda, Y Saito, S Terai, T Hayashi, and Y Sugimoto 2003 Quantitative trait loci analysis for growth and carcass traits in a Meishan x Duroc F2 resource population. Journal of Animal Science 81 2938-2949.

Sellier, P, V Cousin, and P Dando 1987 Effects of halothane sensitivity on male and female reproductive performance in Pietrain lines. Annales de Zootechnie 36 249-263.

Short, TH, MF Rothschild, OI Southwood, DG McLaren, Ad Vries, Hvd Steen, GR Eckardt, CK Tuggle, J Helm, DA Vaske, AJ Mileham, and GS Plastow 1997 Effect of the estrogen receptor locus on reproduction and production traits in four commercial pig lines. Journal of Animal Science 75 3138-3142.

Slatkin, M 2009 Epigenetic inheritance and the missing heritability problem. Genetics 182 845-850.

Spotter, A, S Muller, H Hamann, and O Distl 2009 Effect of polymorphisms in the genes for LIF and RBP4 on litter size in two German pig lines. Reproduction in Domestic Animals 44 100-105.

Stinckens, A, P Mathur, S Janssens, V Bruggeman, OM Onagbesan, M Schroyen, G Spincemaille, E Decuypere, M Georges, and N Buys 2010 Indirect effect of IGF2 intron3 g.3072G > A mutation on prolificacy in sows. Animal Genetics 41 493-498.

Tribout, T, JC Caritez, J Gogué, J Gruand, Y Billon, J Le Dividich, H Quesnel, and JP Bidanel 2003 Estimation of realised genetic trend in French Large white pigs from 1977 to 1998 using frozen semen : results for some female reproduction traits. Journees de la Recherche Porcine en France 35 285-292.

Tribout, T, N lannuccelli, T Druet, H Gilbert, J Riquet, R Gueblez, M-J Mercat, J-P Bidanel, D Milan, and P Le Roy 2008 Detection of quantitative trait loci for reproduction and production traits in Large White and French Landrace pig populations. Genetics Selection Evolution 40 61-78.

Vallet, JL, BA Freking, KA Leymaster, and RK Christenson 2005 Allelic variation in the erythropoietin receptor gene is associated with uterine capacity and litter size in swine. Animal Genetics 36 97-103.

Van Laere, AS, M Nguyen, M Braunschweig, C Nezer, C Collette, L Moreau, AL Archibald, CS Haley, N Buys, M Tally, G Andersson, M Georges, and L Andersson 2003 A regulatory mutation in IGF2 causes a major QTL effect on muscle growth in the pig. Nature 425 832-836.

Van Rens, BTTM, GJ Evans, and T Van der Lende 2003 Components of litter size in gilts with different prolactin receptor genotypes. Theriogenology $\mathbf{5 9}$ 915-926.

Van Rens, BTTM, PNd Groot, and T Van der Lende 2002 The effect of estrogen receptor genotype on litter size and placental traits at term in F2 crossbred gilts. Theriogenology 57 1635-1649.

Van Rens, BTTM, and T Van der Lende 2002 Litter size and piglet traits of gilts with different prolactin receptor genotypes. Theriogenology 57 883-893.

Vincent, AL, G Evans, TH Short, OI Southwood, GS Plastow, CK Tuggle, and MF Rothschild 1998 The prolactin receptor gene is associated with increased 
litter size in pigs. Proceedings of the 6th World Congress on Genetics Applied to Livestock Production, Armidale, Australia, January 11-16, 1998. Volume 27: Reproduction; fish breeding; genetics and the environment; genetics in agricultural systems; disease resistance; animal welfare; computing and information technology; tree breeding. 15-18.

Wilkie, PJ, AA Paszek, CW Beattie, LJ Alexander, MB Wheeler, and LB Schook 1999 A genomic scan of porcine reproductive traits reveals possible quantitative trait loci (QTLs) for number of corpora lutea. Mammalian Genome 10 573-578.

Xing, Y, J Ren, D Ren, Y Guo, Y Wu, G Yang, H Mao, B Brenig, and L Huang 2009 A whole genome scanning for quantitative trait loci on traits related to sperm quality and ejaculation in pigs. Animal Reproduction Science 114 210-218.
Yang, G, J Ren, S Li, H Mao, Y Guo, Z Zou, D Ren, J Ma, and L Huang 2008 Genome-wide identification of QTL for age at puberty in gilts using a large intercross F2 population between White Duroc * Erhualian. Genetics, Selection, Evolution 40 529-539.

Yonggang, L, and X Xueshan 2012 Molecular characterization, tissue expression, polymorphism and association of porcine LCK gene. Molecular biology reports 39 4023-4028.

Zhao, HH, MF Rothschild, RL Fernando, and JCM Dekkers 2003 Tests of candidate genes in breed cross populations for QTL mapping in livestock. Mammalian Genome 14 472-482.

Zuk, O E Hechter, SR Sunyaev, and ES Lander 2012 The mystery of missing heritability: genetic interactions create phantom heritability. Proceedings of the National Academy of Sciences of the United States of America 109 1193-1198. 